\title{
Srečanje Evropske mikološke mreže v Sloveniji 2015
}

\section{Nikica OGRIS ${ }^{1^{*}}$}

Evropska mikološka mreža (ang. European Mycological Network, EMN) je panevropska skupina diagnostičnih mikologov, ki je bila ustanovljena leta 1997. Najpomembnejšo aktivnost EMN predstavlja forum za razpravo o zanimivih temah iz mikologije in bolezni rastlin s poudarkom na karantenskih glivah. Do leta 2014 je EMN sodelovala $\mathrm{z}$ Evropsko in mediteransko organizacijo za varstvo rastlin (ang. European and Mediterranean Plant Protection Organization, EPPO) pri pripravi diagnostičnih protokolov za glivične bolezni rastlin. Od leta 2014 naprej to nalogo opravlja nov EPPO panel za diagnozo v mikologiji. EMN uresničuje svoj glavni cilj z dopisnimi sejami in letnim srečanjem, ki je vsako leto $\mathrm{v}$ drugi državi članici (28 držav članic). V letu 2015 je bilo EMN srečanje v Sloveniji (slika 1) in v nadaljevanju podajamo najzanimivejše novosti iz področja varstva gozdov.

Od leta 2000 naprej se kar naprej množijo zabeležke poškodb divjega kostanja (Aesculus hippocastanum L.) zaradi parazitske bakterije Pseudomonas syringae pv. aesculi (Report on ..., 2008). Pred letom 2000 so izcejanje črnega soka in odmiranje skorje na divjem kostanju (slika 2) večinoma pripisovali poškodbam zaradi glivolikih alg Phytophthora cactorum (Lebert \& Cohn) J. Schröt. in Phytophthora citricola Sawada. Omenjeno bakterijo so nedavno našli tudi v Nemčiji (Heupel, 2015), kjer so v kasnejših fazah bolezni našli na obolelem drevju še druge parazitske glive, npr. iz rodov Flammulina, Nectria in Pleurotus.

Parazitska gliva Cryptocline taxicola (Allesch.) Petr. povzroča obsežne poškodbe na tisi (Taxus baccata L.) v Angliji (Perez-Sierra, 2015a). V prvi fazi povzroča rumenjenje iglic, ko pa bolezen napreduje, iglice odmrejo in porjavijo. Bolezen lahko prepoznamo po velikih črnih trosiščih na zgornji in spodnji strani odmrlih iglic (slika 3). Zaznali so tudi povečan obseg poškodb zaradi glive Sirococcus conigenus (DC.) P.F. Cannon \& Minter, ki povzroča bolezen odmiranja smrekovih poganjkov in povzroča sušenje iglic in poganjkov različnih iglavcev (slika 4). V letu 2008 so posodobili opis vrste Sirococcus conigenus in opisali dve novi, zelo podobni vrsti gliv:

- S. conigenus ima veliko število gostiteljev, to so predvsem bori, smreke, macesni in duglazija po vsej severni polobli;

- $\quad$ S. piceicola Rossman, Castl., D.F. Farr \& Stanosz glavni gostitelj so smreke, pojavlja se v Kanadi in Švici;

- $\quad$ S. tsugae Castl., D.F. Farr \& Stanosz - okužuje večinoma iglavce iz rodu Tsuga in Cedrus, doslej je bila znana predvsem iz Severne Amerike. V letu 2014 je povzročila veliko poškodb v Angliji na čugi, nedavno pa so jo našli tudi v Nemčiji na atlantski cedri (Cedrus atlantica (Endl.) Carriere).
Najpomembnejši in najpogostejši škodljivi organizmi v Angliji so iz rodu Phytophthora (Perez-Sierra, 2015b), ki je konec leta 2014 obsegal 142 vrst. Najpomembnejše fitoftore v Angliji so P. siskiyouensis Reeser \& E.M. Hansen, P. plurivora T. Jung \& T.I. Burgess, $P$. cinnamomi Rands, $P$. ramorum Werres, De Cock \& Man in 't Veld. P. siskiyouensis je nova izredno patogena vrsta, ki ima za gostitelje vse vrste jelše (Alnus). Prvič je bila opisana v Oregonu leta 2007. Širi se z zoosporami $\mathrm{v}$ potokih in rekah. $P$. siskiyouensis je mnogo bolj virulentna kot avtohtona P. alni Brasier \& S.A. Kirk, ki je bila ugotovljena tudi v Sloveniji. Prepoznamo jo po tipičnih črnih izcedkih na skorji jelš, nekrozah v skorji in prebarvanju lesa. Temperaturni optimum ima ok. $25^{\circ} \mathrm{C}$. Testi patogenosti so pokazali, da je med jelšami najbolj občutljiva črna jelša (A. glutinosa (L.) Gaertn.), na drugem mestu je zelena jelša (A. viridis (Chaix) DC.), na tretjem mestu pa siva jelša (A. incana (L.) Moench). V Angliji so določili še dve novi vrsti fitoftor, tj. P. ilicis Buddenh. \& Roy A. Young, katere glavni gostitelj je Ilex aquifolium L., in P. gallica T. Jung \& Nechw., katere glavni gostitelji so črna jelša, navadna bukev (Fagus sylvatica L.), dob (Quercus robur L.), lipe (Tilia L.) in vrbe (Salix L.). Glivoliko algo P. gallica so izolirali iz vzorca zemlje pod hirajočim dobom v severovzhodni Franciji in jugozahodni Nemčiji. Na Škotskem in severni Angliji so v 2011 izolirali še eno vrsto iz rodu fitoftor, tj. $P$. austrocedri Gresl. \& E.M. Hansen, ki je bila prvič opisana na Austrocedrus chilensis (D.Don) Pic.Serm. \& Bizzarri v Argentini v letu 2007 (Schlenzig, 2015). V Angliji se pojavlja na brinu (Juniperus L.), Lawsonovi pacipresi (Chamaecyparis lawsoniana (A. Murray) Parl.) in nutkodolski pacipresi (Chamaecyparis nootkatensis (D. Don) Spach). Sicer pa se število vrst fitoftor hitro povečuje zaradi njihove sposobnosti hibridizacije (Van Poucke in sod., 2015). Hibridi (križanci) fitoftore so pomembni zato, ker so lahko bolj agresivni kot starševske vrste in imajo pogosto širši nabor gostiteljev. K hibridizaciji fitoftor prispeva pestrost ekosistemov (gozdovi, reke, drevesnice) in raznoliko podnebje v Evropi. Razvili so dve napredni molekularni metodi za detekcijo novih hibridov fitoftor (Van Poucke in sod., 2015).

Na Norveški so določili invazivno tujerodno vrsto glivo Delphinella abietis (O. Rostr.) E. Müll.), ki povzroča odmiranje jelovih poganjkov (slika 5) (Talgø in sod., 2015). Nevede so jo uvozili z okrasnimi sadikami jelke iz Severne Amerike, kjer je gliva domorodna. Nekatere vrste jelk so zelo občutljive, kot npr. Abies lasiocarpa (Hooker) Nuttall, ki jo na Norveškem množično gojijo v drevesnicah kot božično drevo. V Nemčiji pa se spopadajo s problemom sušenja mladja jelk zaradi glive iz rodu Lachnellula (Schumacher in sod., 2015).

Na Hrvaškem so na petih lokacijah v Dalmaciji našli karantensko glivo Lecanosticta acicola (na seznamu II/A1 v Direktivi Sveta 2000/29/ES) na alepskem boru 
(Pinus halepensis Miller) (Diminić in sod., 2015). Gliva L. acicola povzroča rjavenje borovih iglic (slika 6) in spada med najpomembnejše bolezni bora. Na Hrvaškem so jo našli že 1975 (Glavaš in Margaletić, 2001), kjer se večinoma pojavlja $\mathrm{v}$ gostih plantažah alepskega bora in na naravnem mladju. $Z$ raziskavo so ugotovili, da se širi s pomočjo vetra in da povzroča največ poškodb na vlažnih rastiščih (Diminić in sod., 2015).

Pri izkoreninjanju tujerodnih invazivnih vrst je najpomembnejše njihova hitra detekcija, saj velja pravilo: prej ko jih najdemo, več možnosti imamo za njihovo izkoreninjenje. Za hitro detekcijo nam lahko pomagajo različne vrste kontrolnih pasti za trose gliv. Lastnosti "dobre" kontrolne pasti so naslednje (Chandelier in Heungens, 2015): (1) ni predraga, (2) enostavno jo postavimo in ima majhno maso, (3) ima visoko učinkovitost ulova, (4) prilagojena je za ulov različnih vrst trosov. V Belgiji so preskušali tri vrste pasti, tj. Whatman (na osnovi filtra, pasiven sistem), Burkard (volumetrična past, aktiven sistem s pretokom zraka) in RST (past z rotirajočo ročko, aktiven sistem), ki so jo razvili sami (slika 7) (Chandelier in Heungens, 2015). Če upoštevamo vse lastnosti "dobre" kontrolne pasti, se je najbolje med vsemi odrezala RST past.

Piškur (2015) je v okviru podoktorskega projekta predstavila raziskave o rjah iz rodu Melampsora na vrbah, topolih in na nekaterih drugih lesnatih rastlinah $\mathrm{v}$ Sloveniji. Določila je več vrst rj: M. betulinum Desm. (na črni jelši in navadni brezi), M. hiratsukanum Ito (na sivi jelši), na topolih in macesnu: $M$. laricis-epitea $\mathrm{f}$. sp. laricis-epitea typica Klebahn, M. laricis-caprearum Kleb., Melampsora ribesii-purpureae Kleb., M. laricispopulina Kleb. Pomembna je bila potrditev prisotnosti tujerodne invazivne vrste $M$. hiratsukanum, ki verjetno izvira iz Azije in se v zadnjih 20-30 letih hitro širi po Evropi. Razvita metodologija iz te raziskave bo pomagala gozdarski stroki pri določevanju rj.

V Švici so potrdili povezavo med kostanjevo šiškarico (Dryocosmus kuriphilus Yasumatsu) in kostanjevim rakom (Cryphonectria parasitica (Murrill) M.E. Barr) (Prospero in Forster, 2011; Prospero in Meyer, 2015). C. parasitica lahko okuži opuščene šiške in se razraste $\mathrm{v}$ vejico, kjer povzroča odmiranje skorje in lahko oblikuje rak (slika 8). Izhodna odprtina iz šiške predstavlja rano na drevesu in hkrati vstopno mesto za glivo, ki povzroča kostanjev rak. Z raziskavo so ugotovili, da je povprečno 7,2 \% šišk okuženih z glivo C. parasitica. Razlika med gozdnimi sestoji je lahko velika, saj je okuženost šišk lahko samo 2,5\%, lahko pa doseže do $17 \%$. Kostanjeve šiške večinoma okuži virulentna oblika glive, tj. brez virusov, kar bo verjetno povečalo pogostost virulentne oblike kostanjevega raka v gozdnih sestojih. Kako obsežne posledice bodo za pravi kostanj zaradi tega pojava še ni znano.

\section{Viri}

Chandelier A., Heungens K. 2015. Comparison between different spore traps combined with qPCR for the detection of the airborne inoculum of fungi in the forest. 18. letno srečanje Evropske mikološke mreže, Ljubljana, 21.-23. april 2015

Diminić D., Devčić Buzov I., Kranjec J., Milotić M. 2015. Research update on Mycosphaerella dearnessii Barr. on Pinus halepensis Mill. in Croatia. 18. letno srečanje Evropske mikološke mreže, Ljubljana, 21.-23. april 2015

Glavaš M., Margaletić J. 2001. Smeđa pjegavost iglica alepskoga bora i mjere zaštite. V: Znanost u potrajnom gospodarenju hrvatskim šumama: znanstvena knjiga. Matić S., Krpan A.P.B., Gračan J. (Ur.): 277-284

Heupel M. 2015. New and unusual findings in North-Rhine Westphalia. 18. letno srečanje Evropske mikološke mreže, Ljubljana, 21.-23. april 2015

Heupel M., Tiede-Arlt Peter. 2007. Blutende Kastanien durch neuen Krankheitserreger. Landwirtschaftskammer Nordrhein-Westfalen. Vir: https://www.landwirtschaftskammer.de/landwirtschaft/pflanzenschutz/oeffentlichesgruen/kastanienbluten.htm

Perez-Sierra A. 2015a. Diseases detected at the Tree Health Diagnostic \& Advisory Service. 18. letno srečanje Evropske mikološke mreže, Ljubljana, 21.-23. april 2015

Perez-Sierra A. 2015b. Phytophthora spp. on trees. 18. letno srečanje Evropske mikološke mreže, Ljubljana, 21.-23. april 2015

Piškur B. 2015. Rust survey on trees in Slovenia. 18. letno srečanje Evropske mikološke mreže, Ljubljana, 21.-23. april 2015

Prospero S., Forster B. 2011. Chestnut gall wasp (Dryocosmus kuriphilus) infestations: new opportunities for the chestnut blight fungus Cryphonectria parasitica? New Disease Reports (2011) 23, 35. [http://dx.doi.org/10.5197/j.2044-0588.2011.023.035]

Prospero S., Meyer J. 2015. Interactions between the chestnut blight fungus Cryphonectria parasitica and the chestnut gall wasp Dryocosmus kuriphilus. 18. letno srečanje Evropske mikološke mreže, Ljubljana, 21.-23. april 2015

Report on the national survey to assess the presence of bleeding canker of horse chestnut trees in Great Britain. Forestry Commission, Plant Health Service, Edinburgh, 2008

Schlenzig A. 2015. The detection of Phytophthora austrocedri. 18. letno srečanje Evropske mikološke mreže, Ljubljana, 21.-23. april 2015

Schumacher J., Reinbold J., Dounavi A. 2015. Der Lachnellula-Krebs an Abies alba - ein neuartiges Krankheitsphänomen in den TannenGebieten des Schwarzwaldes. Jarbuch der Baumpflege 2015

Talgø V., Skage J.O., Steffenrem A., Johnskås R. 2015. Damage by Delphinella abietis on subalpine fir in Norway may depend on the origin of the seed source. Joint IUFRO 7.02.02 "Foliage, shoot and stem diseases of forest trees" and 7.03.04 "Diseases and insects in forest nurseries" - Uppsala, Sweden on the 7 - 12th June 2015.

Van Poucke K., Goedefroit T., Chandelier A., Heungens K. 2015. Detection of Phytophthora hybrids. 18. letno srečanje Evropske mikološke mreže, Ljubljana, 21.-23. april 2015

${ }^{1}$ Gozdarski inštitut Slovenije, Večna pot 2, 1000 Ljubljana "nikica.ogris@gozdis.si 


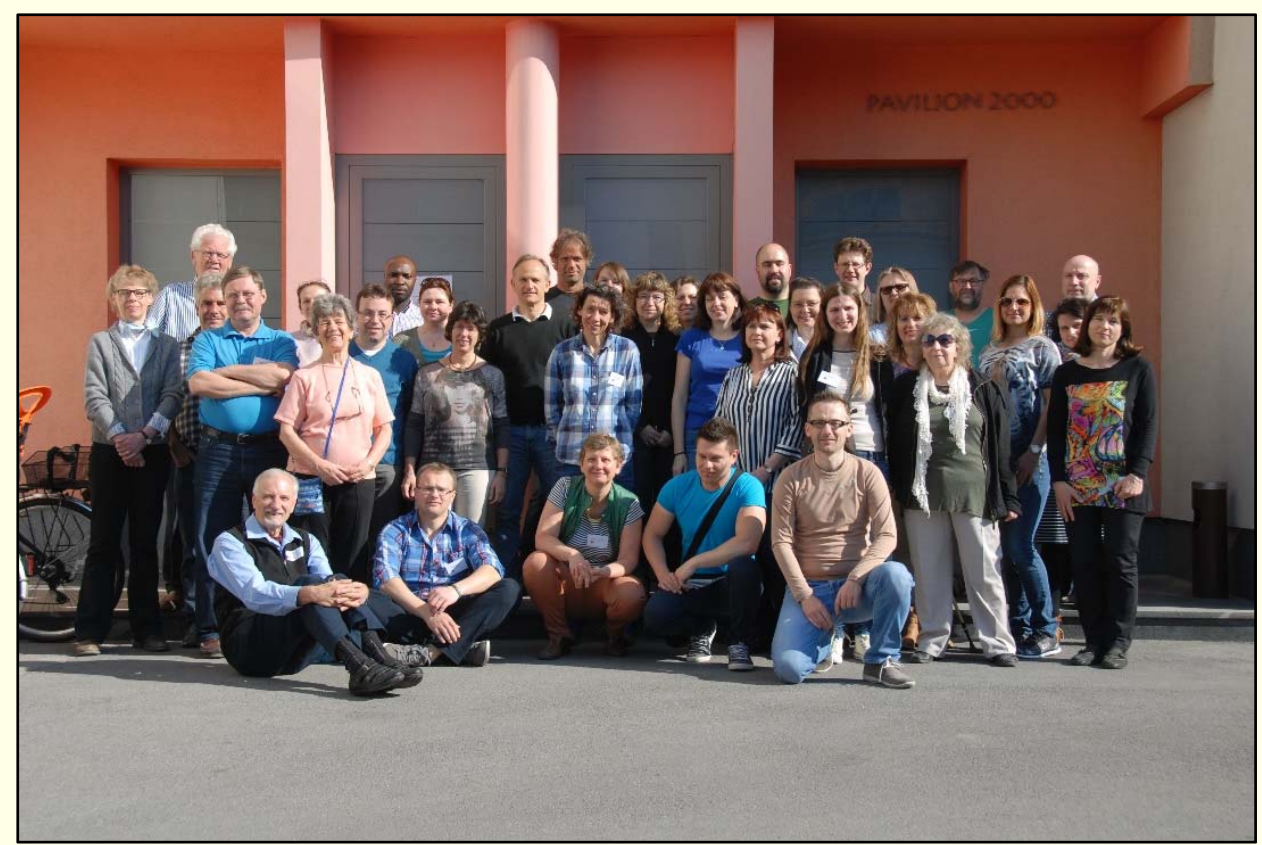

Slika 1: Skupinska slika udeležencev 18. srečanja Evropske mikološke mreže v Ljubljani 2015

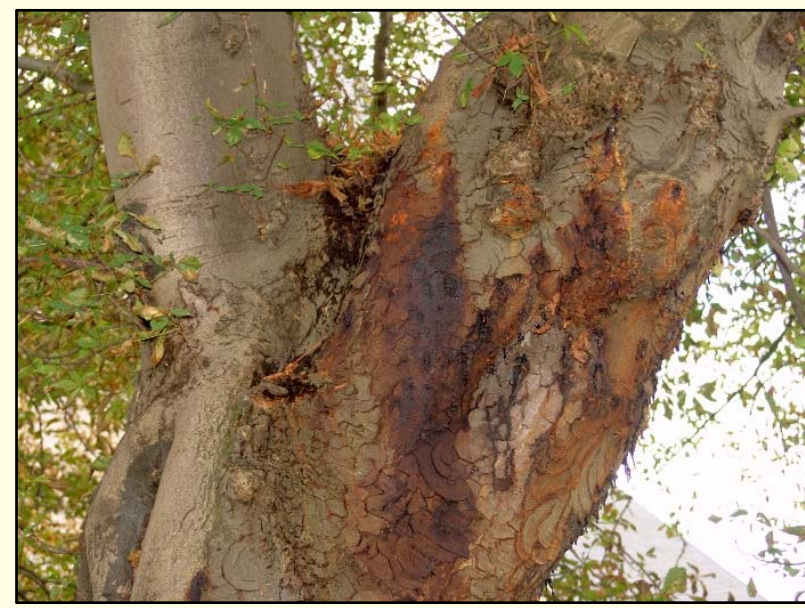

Slika 2: Izcejanje črnega soka iz skorje divjega kostanja zarad bakterije Pseudomonas syringae pv. aesculi (foto. Monika Heupel) (Heupel in Tiede-Arlt, 2007)

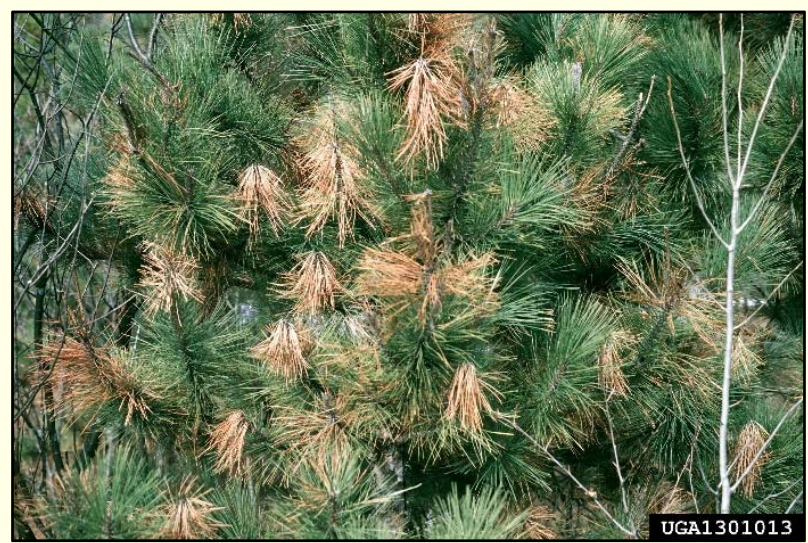

Slika 4: Sušenje poganjkov smreke zaradi glive Sirococcus conigenus (Joseph O'Brien, USDA Forest Service, Bugwood.org)

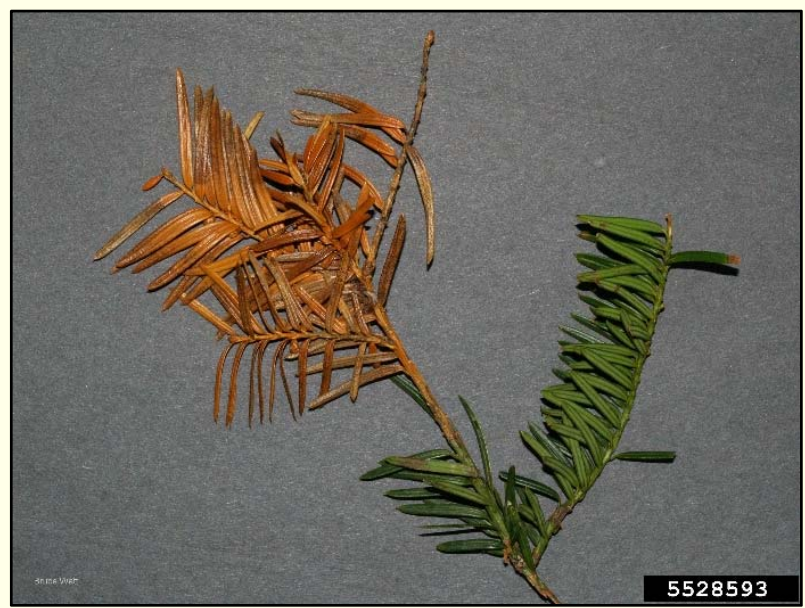

Slika 3: Odmrle iglice navadne tise in črna trosišča glive Cryptocline taxicola (foto. Bruce Watt, University of Maine, Bugwood.org)

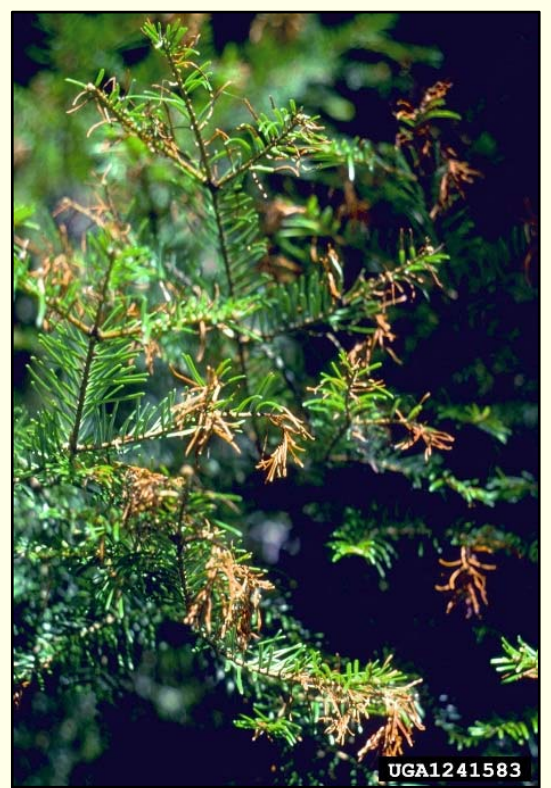

Slika 5: Odmiranje jelovih poganjkov zaradi glive Delphinella abietis (Susan K. Hagle, USDA Forest Service, Bugwood.org) 


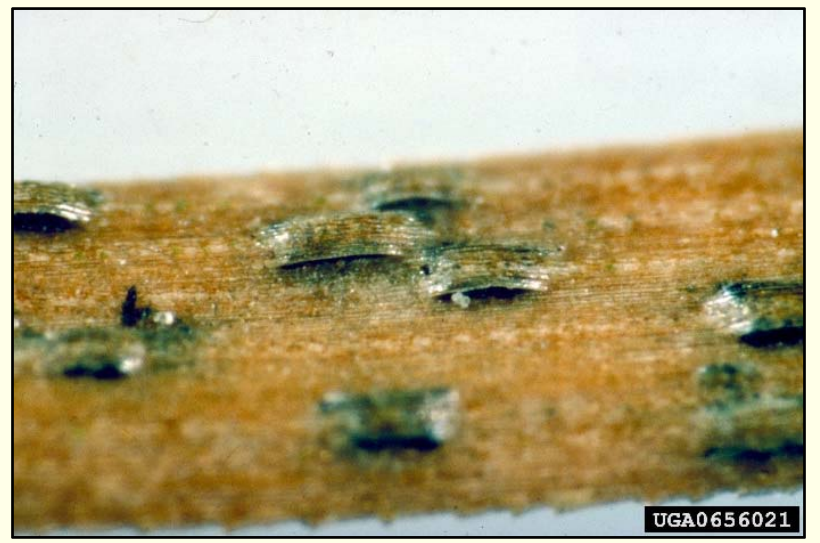

Slika 6: Trosišča glive Lecanosticta acicola na borovih iglicah (H.C. Evans, CAB Interational, Bugwood.org)

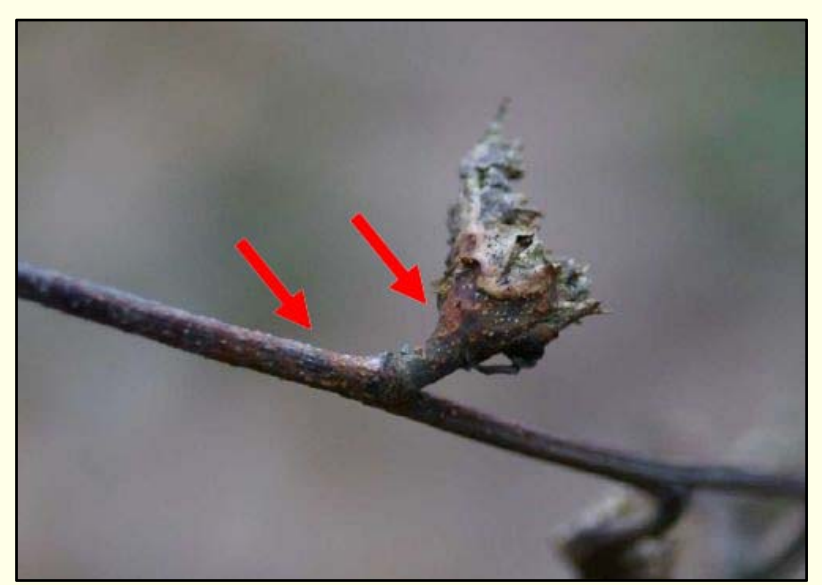

Slika 8: Odmiranje skorje zaradi glive Cryphonectria parasitica, ki je okužila vejico skozi šiško (Prospero in Forster, 2011)

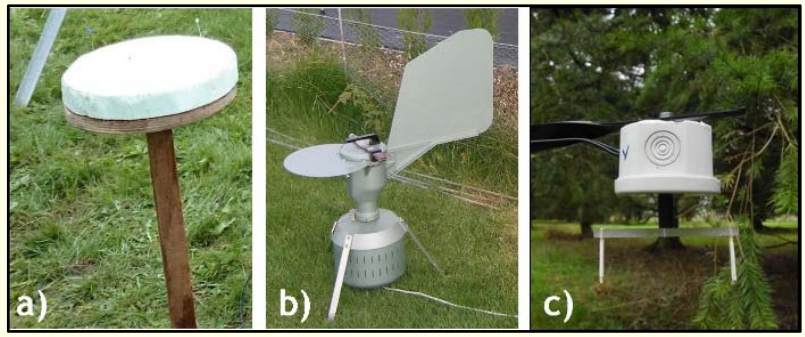

Slika 7: Različni tipi lovilcev trosov - kontrolne pasti: a) Whatman, b) Burkard, c) RST past (Chandelier in Heungens, 2015) 